\title{
Gas engine driven heat pump - characteristics, analysis of applications in buildings energy systems
}

\author{
Adam Ruciński, Artur Rusowicz, Andrzej Grzebielec \\ Warsaw University of Technology, Politechniki 1 Street, 00-650 Warsaw, Poland
}

\begin{abstract}
The paper concerns in particular gas engine driven heat pump. It presents where in the industry the heat pump is used with a mechanical drive. There are mentioned the main directions of development and first of all pumps driven by gas engine. The paper provides an overview of the advantages and disadvantages of this approach and circuit diagrams reproduced with heat pumps powered by a gas engine. Simple comparison shows the emissions for the creation of electricity (electric motor) and mechanical power (gas engine). A review of applications of gas engine driven heat pumps in Poland and abroad is presented. The basic parameters of the systems, principles of operation, operational problems and approximate costs are mentioned.
\end{abstract}

Keywords: heat pump; gas engine; building's energy system.

\begin{tabular}{|ll|}
\hline Nomenclature \\
COP & Coefficient of Performance \\
E & Electric power, W \\
G & Power supplied with fuel stream, W \\
GEHP & Gas Engine driven Heat Pump \\
HVAC & Heat, Ventilation and Air Conditioning \\
PER & Primary Energy Ratio \\
Q & upper heat source power, W \\
$\eta$ & electricity generation efficiency \\
\hline
\end{tabular}

\section{Introduction}

The current international arrangements relating to the consumption of fossil fuels are obvious - they must be used in a very cost-effective way. It is found that the operating costs associated with heating and air conditioning of buildings are about $80 \%$ of operating facilities. Therefore, proper design and selection of heating and air-conditioning equipment are very important due to the subsequent operating costs. The choice of technology limiting energy consumption significantly reduces the TCO (Total Cost of Ownership).

Gas engine driven heat pumps (GEHP) generate heat flux both of superheating and condensation of the working fluid, the cooling load and electricity. Additionally, there is heat flux coming from cooling of gas engine combustion chamber. This is tri-generation which allows to utilize the primary energy with higher efficiency. It is one of the best solutions for buildings with a high demand for hot water (SPA facilities, water parks, hotels and industrial processes). Previous experiences with GEHPs in heating and cooling systems in buildings confirmed operational savings of about $40 \%$. Additionally, this reduces the need for external electrical power and space savings due to the lack of need for technical rooms. For many users of the building operating costs can be settled on the individual tenants according to actual consumption of heat in the winter and cooling in the summer.

Corresponding author: Adam Ruciński. E-mail address: ruciński@itc.pw.edu.pl

http://dx.doi.org/10.3846/enviro.2014.280

(C) 2014 The Authors. Published by VGTU Press. This is an open-access article distributed under the terms of the Creative Commons Attribution License, which permits unrestricted use, distribution, and reproduction in any medium, provided the original author and source are credited. 


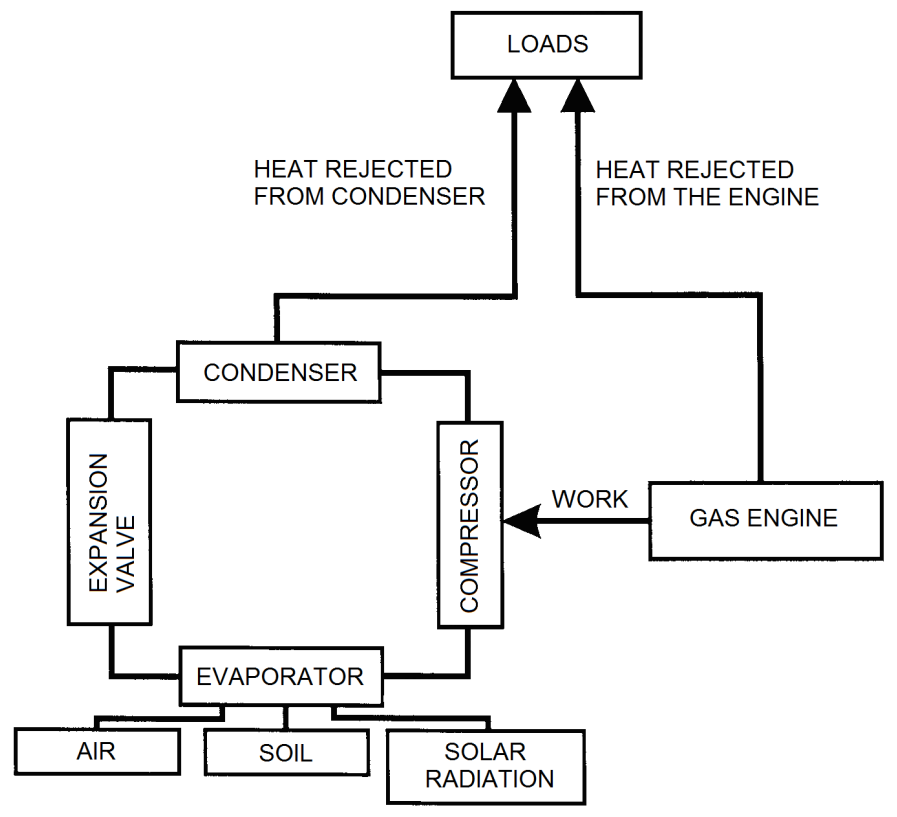

Fig. 1. The use of renewable heat sources with gas engine driven heat pump

Increasing of the energy efficiency could be achieved in various ways. One of them is the use of high efficient gas engines used for driving of modern compressors. These solutions have been introduced in the middle of the first decade of the twenty-first century in Japan - now they are used in many European countries. Heat pump compressor is driven by a rotating shaft using a gas engine. Thus, in the system with a heat pump electricity is used mainly to drive components such as fans, control systems. Compared to conventional drive (electric motor) electricity demand is much smaller.

\section{Characteristics of gas engine driven heat pumps}

There are some features of gas engine driven heat pumps [1]:

- low consumption of electricity,

- higher energy efficiency due to cogeneration of heat, cold and electricity (good solution in regions with low annual temperature),

- modern gas engine provides a reduction of carbon dioxide emissions,

- no need of electric defrostation of evaporator - a warm water from the engine cooling is used.

Table 1. Usage of heat pumps [2]

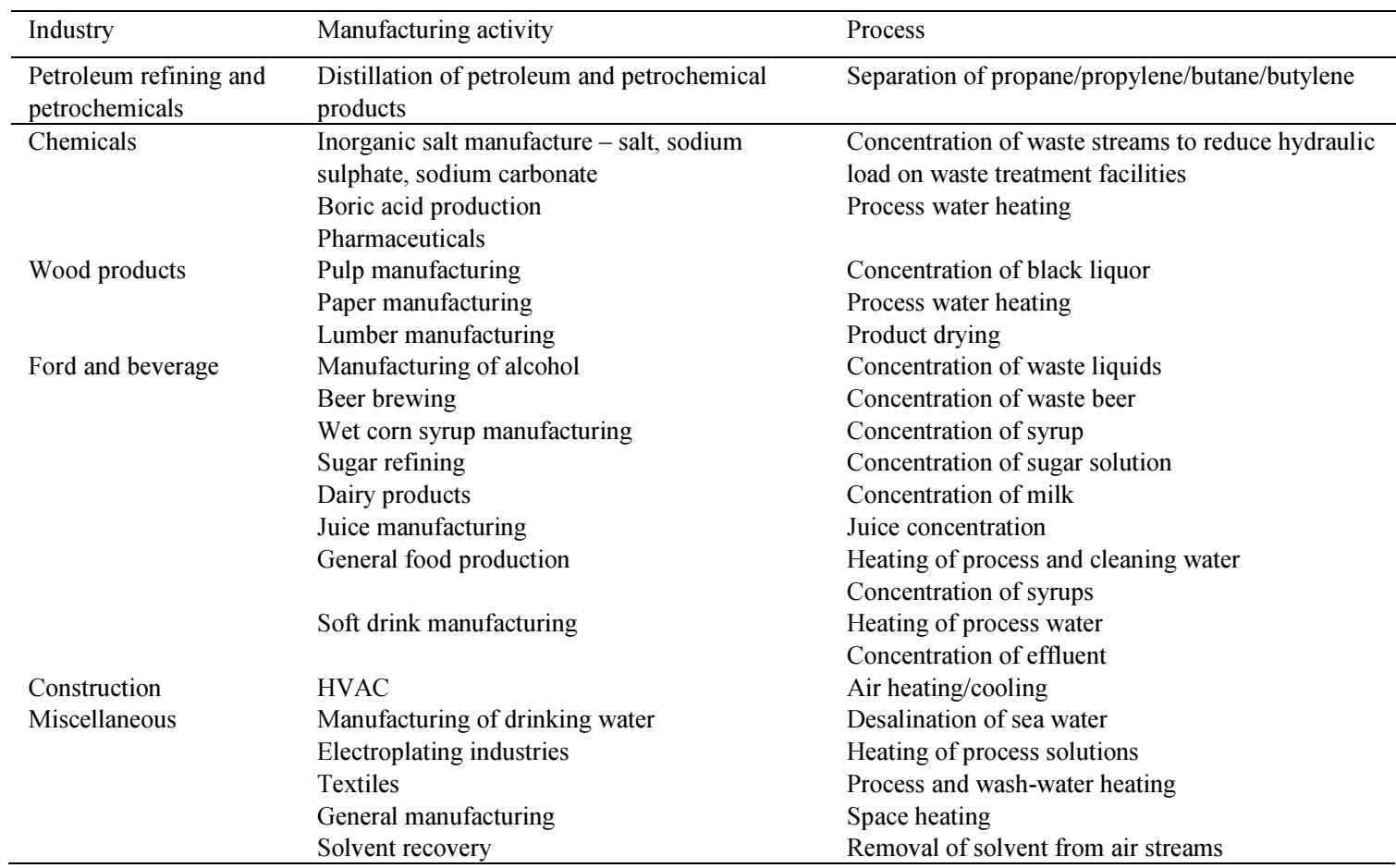




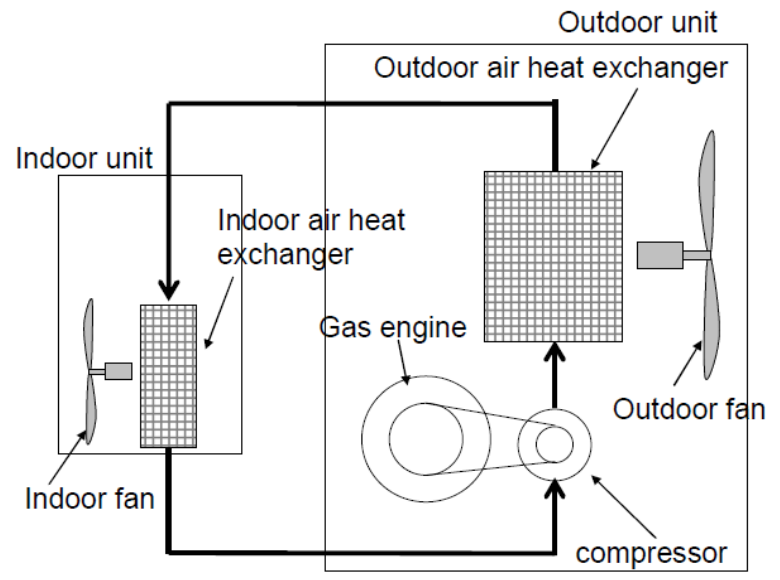

Fig. 2. Application of gas engine driver heat pump in air conditioning

Operational problems concern the vibrations and movements associated with the transmission ratios of the motor shaft to the compressor shaft. Another problem is the noise emission. Gas drive system requires regular maintenance treatments: oil change, replacement of oil and air filters, replacement of spark plugs.

Better energy efficiency was achieved by the use of high-performance scroll compressors. Good results were achieved using a continuous speed control system. The variability of the volume of pressurized refrigerant and cooling capacity was achieved. As a result of further studies, it was found that the best working fluid is a HFC-410A [3] because of its good cooling capacity per unit volume.

Table 2. Specification of chosen GEHPs [2]

\begin{tabular}{|c|c|c|c|c|}
\hline Model & $450 \mathrm{MT} 7$ & $560 \mathrm{MT} 7$ & $450 \mathrm{G} 1$ & $840 \mathrm{Gl}$ \\
\hline Capacity (Cooling/Heating), kW & $45 / 50$ & $56 / 63$ & $45 / 50$ & $84 / 95$ \\
\hline $\begin{array}{l}\text { Gas consumption (Cooling/Heating) (transferred to } \\
\text { delivered power), } \mathrm{kW}\end{array}$ & $30.5 / 29.1$ & $41.5 / 38.0$ & $27.4 / 29.6$ & $56.0 / 57.9$ \\
\hline \multicolumn{5}{|l|}{ Electric power consumption $(60 \mathrm{~Hz})$} \\
\hline (Cooling/Heating), kW & $1.12 / 1.21$ & & $1.03 / 1.19$ & $1.77 / 1.67$ \\
\hline COP (average for the cooling and heating modes) & 1.54 & 1.46 & 1.60 & 1.52 \\
\hline \multicolumn{5}{|l|}{ External measurements, mm } \\
\hline Height & 2250 & & 2176 & 2176 \\
\hline Width & 1750 & & 1990 & 2985 \\
\hline Depth & 1080 & & 800 & 800 \\
\hline Mass, $\mathrm{kg}$ & 920 & & 940 & 1270 \\
\hline
\end{tabular}

It is known that the investment costs for the installation of a gas-powered heat pump are higher compared to the electric drive. Cost-effectiveness of heat pump relies on cheaper charges for the supply of gas compared to the higher cost of electricity delivery.

It is difficult to compare the efficiency of electric driven heat pump with GEHP according to the problem with correct expression of the reference level. A method based on estimating the ratio of PER was developed, which indicates the efficiency of the power consumption resulting from the primary energy [4]. For the electric heat pump efficiency is defined in Eqn (1) where Q is the power used in the upper heat source of heat pump, and E is the electric power supplied to the heat pump and $\eta_{\mathrm{el}}$ is electricity generation efficiency.

$$
P E R_{E H P}=\frac{Q}{E} \cdot \eta_{e l}
$$

In the case of heat pumps with gas engine PER ratio is expressed in Eqn (2), where Q is the useful power at the upper heat source, E is the electric power supplied to the heat pump (fans supply, control system). $G$ is the power supplied to the heat pump calculated in the base on both calorific value and volume flow rate of the gas.

$$
P E R_{G E H P}=\frac{Q}{G+E \cdot \frac{1}{\eta_{e l}}}
$$


In the case of heat pumps with gas engine PER ratio is expressed in Eqn (2), where Q is the useful power at the upper heat source, E is the electric power supplied to the heat pump (fans supply, control system). $G$ is the power supplied to the heat pump calculated in the base on both calorific value and volume flow rate of the gas.

A proper comparison should be done including information about the operating temperature ranges, streams volume of the working fluid and way of obtaining a heat flux from the lower-source heat pump.

The literature shows the ecological goodness of gas combustion which results in low emission of harmful products. The stoichiometric calculations are compared - for coal and methane gas combustion used in electricity production. This can be done for the heat pump SGP-E190K1GU2W: cooling capacity of gas engine driver heat pump is $56 \mathrm{~kW}$, input power of gas is $34 \mathrm{~kW}$.

The necessary assumptions were done: particularly the efficiency of current generator, the mechanical efficiency of the steam turbine, the power of the boiler and fuel flow. The necessary stoichiometric calculations [6] lead to presentation of emission components placed in Table 3.

Table 3. Emission of flue gases [6]

\begin{tabular}{llll}
\hline Engine used & & Electric engine & Gas engine \\
\hline Fuel stream, $\mathrm{kg} / \mathrm{h}$ & & 20.11 & 2.33 \\
Flue gases $\left[\mathrm{m}^{3} / \mathrm{h}\right]:$ & Carbon dioxide & 20.34 & 3.31 \\
& Carbon monoxide & 0.40 & 0.30 \\
& $\mathrm{NO}_{\mathrm{x}}$ & 12.68 & 25.20 \\
& $\mathrm{SO}_{\mathrm{x}}$ & 0.09 & - \\
\hline
\end{tabular}

Results show lower carbon dioxide emission, slightly less carbon monoxide but higher $\mathrm{NO}_{\mathrm{x}}$ emission. Due to the absence of sulphur in the fuel gas in the combustion products there are not sulphur oxides harmful for natural environment.

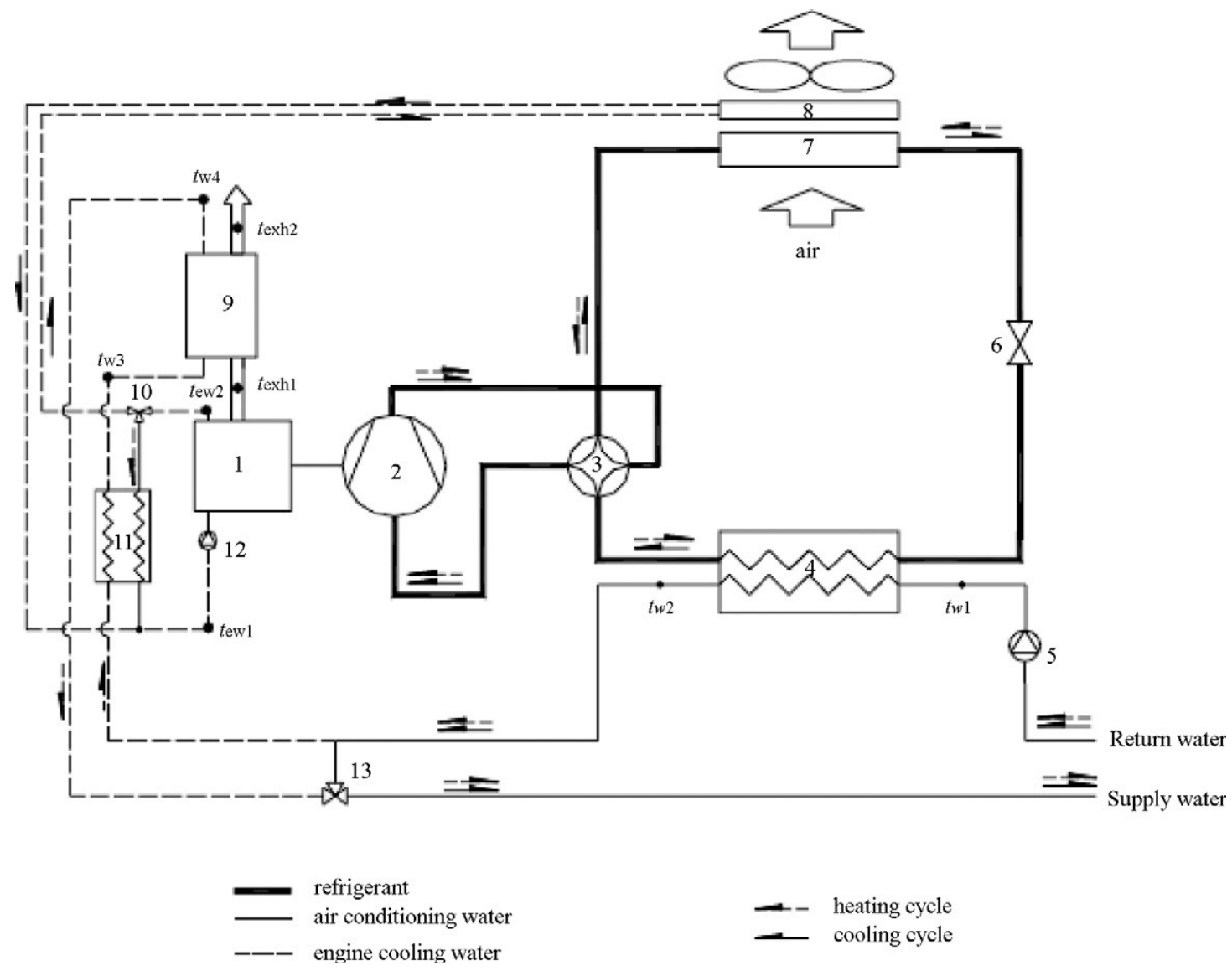

Fig. 3. GEHP's scheme: 1 - gas engine, 2 - open compressor, 3 - four-way valve, 4 - plate heat exchanger, 5 - supply water pump, 6 - expansion valve, 7 - finned-tube heat exchanger, 8 - heat radiator, 9 - gas-water heat exchanger , 10 - three-way valve, 11 - water-water heat exchanger, 12 - cooling water pump, 13 - three-way valve [5] 


\section{Systems with GEHPs}

\section{1. $R \& D$ center in Lysomice, Poland}

On the surface of over 5 hectares a modern research-production unit is placed about the total $14816.69 \mathrm{~m}^{2}$ usable area. The object was put into operation in March 2012. He consists of the office part about the area of $4100 \mathrm{~m}^{2}$ and $10000 \mathrm{~m}^{2}$ warehouse-production area. Energy needs of the plant are covered by 11 gas engine driven heat pumps GHP ECO-G WMulti: 5 units with cogeneration, 2 units with water exchangers and 3 units in air handling units. An installed cooling power is $616 \mathrm{~kW}$, the heating power is $693 \mathrm{~kW}$. During the normal working mode about $80 \mathrm{~kW}$ of the thermal power is recovered to produce a warm water. At the same time electric energy is generated in amount of $25.8 \mathrm{~kW}$. The trigeneration systems cover the cooling power demand for the air-conditioning in the summer and heating power demand in the winter. Simultaneously electric energy is produced for center's own needs. The excess energy is used in LED type of energyefficient lighting and electronics.

Annual gas consumption for cooling/heating mode is estimated at $214318 \mathrm{Nm}^{3}$ per year. For traditional system gas consumption was estimated at $238782 \mathrm{Nm}^{3}$ per year. Electricity consumption for cooling/heating mode is estimated at 34.24 MWh per year. In contrast, consumption of electricity for only chiller to provide thermal comfort in summer was estimated at 223.12 MWh per year.

\subsection{Hotel in Cracow, Poland}

Hotel a total area of $9685 \mathrm{~m}^{2}$ was completed in the end of year 2011. There are 9 gas engine driven heat pumps in two VRF air conditioning systems. The installed cooling power is about $500 \mathrm{~kW}$, and the generated heat power is $595 \mathrm{~kW}$. Heat pumps work with the following devices: the individual channel and cassette indoor units, building management system, the global and the local comfort control system. Thermal power and cooling load is generated in the hotel rooms by means of 3-pipes fan-coil systems with full heat recovery. The systems provide maximum comfort and efficiency, especially in spring and autumn. There are 2-pipes fan-coil heating and cooling system is implemented too. They recover heat from the system during cooling mode to heat water. It is free because it comes from combustion engine cooling. In that way there is ability to control individual comfort in every single room.

Gas consumption for cooling/heating mode is estimated at $258328 \mathrm{Nm}^{3}$ per year. For traditional system gas consumption was estimated at $303840 \mathrm{Nm}^{3}$ per year. Electricity consumption for cooling/heating mode is estimated at $45.08 \mathrm{MWh}$ per year. In contrast, consumption of electricity for only chiller to provide thermal comfort in summer was estimated at 10 times more energy used per year.

\section{3. "San Nicola" building in Vicenza, Italy}

The building floor area is about $4200 \mathrm{~m}^{2}$, a volume is $14300 \mathrm{~m}^{3}$ [9]. It consists of three double storey units (A, B, C) and three storey unit D. There is 2 pipes fan-coil heating and cooling system, ventilation and air conditioning system $\left(21700 \mathrm{~m}^{3} / \mathrm{h}\right.$ air handling unit). The heat and cooling load is produced by gas engine driven heat pump and 2 condensing boilers. The engine's work is four stroke Otto cycle with $7440 \mathrm{~cm}^{3}$ total volume of cylinders. Before 1999 year there was traditional system installed with boiler and chiller. In the table there is estimation of costs in actual system compared to boiler plus chiller system. The data show lower expenditures while gas engine driven system has been working since 1999 .

Table 4. Energetic and economic balances in the timeframe 1999-2009

\begin{tabular}{lll}
\hline System & System with GEHP & Boiler plus chiller system \\
\hline $\begin{array}{l}\text { Average gas consumption in heating mode, } \\
\mathrm{Nm}^{3} \text { per year }\end{array}$ & 21763 & 31547 \\
Heating annual average cost, $€ / \mathrm{y}$ & 15059 & 21830 \\
Cooling annual average cost, $€ / \mathrm{y}$ & 14578 & 18117 \\
Ordinary maintenance average cost, $€ / \mathrm{y}$ & 12000 & 9000 \\
Extraordinary maintenance average cost, $€ / \mathrm{y}$ & 2709 & - \\
Half-life major overall of the engine cost, $€ / \mathrm{y}$ & 781 & - \\
Total annual average cost, $€ / \mathrm{y}$ & 45127 & 48947 \\
Primary energy usage 1999-2009, $\mathrm{kWh}$ & 409824 & 478334 \\
Primary energy cost, $€$ & 496393 & 538422 \\
Primary energy savings 1999-2009, $\mathrm{kWh}$ & 68510 & \\
Cost savings 1999-2009, $€$ & 42029 & \\
\hline
\end{tabular}




\section{Summary}

The paper presents the general characteristics of the gas engine driven heat pumps. The features say that these devices have relatively high energy efficiency. It is shown that they are a good alternative to the heat pumps driven by the electric motor. Modern gas engines reduce fuel consumption comparing to traditional way of gas boiler heating (approx. 10\% in Polish examples of GEHP systems). There is lower electricity consumption and better energy balance when cooling mode is considered (no need for external defrostation heat consumption). Besides GEHPs are safe solution in the case of possible electric black-out. Gas engines could protect from discontinuity of electricity supply too. Of course, there is higher investment's cost, some technical problems could occur. However, these devices are well suited for cogeneration systems [11] and may be implemented in a lot of absorption and adsorption processes [7, 8, 10, 12].

\section{References}

[1] Yahagi, M.; Imai, K.; Taniguchi, Y. Development of High-Efficiency Gas Engine Heat Pumps. Report. Japan.

[2] US DOE (Department of Energy) [online]. 2009. Industrial heat pumps for steam and fuel savings. Energy efficiency and renewable energy technical report. Available from Internet: http://www.oit.doe.gov

[3] Hepbasli, A.; Erbay, Z.; Icier, F.; Colak, N.; Hancioglu, E. 2009. A review of gas engine driven heat pumps (GEHPs) for residential and industrial applications, Renewable and Sustainable Energy Reviews 13: 85-99. http://dx.doi.org/10.1016/j.rser.2007.06.014

[4] Jak obliczać sprawność gazowych pomp ciepła? 2011.[How to calculate gas engine heat pump efficiency?] (materiały informacyjne firmy Robur) [information data from Rober company]. Rynek instalacyjny [Installation market], 12

[5] Hepbasli, A.; Kalinci, Y. 2009. A review of heat pump water heating systems, Renewable and Sustainable Energy Reviews 13: 1211-1229. http://dx.doi.org/10.1016/j.rser.2008.08.002

[6] Zarzycki, D. 2007. Analiza zastosowania silnika gazowego do napędu sprężarkowych urzadzeń chtodniczych. [The analysis of gas engine use to drive compressor's cooling machines. Praca dyplomowa [Diploma Thesis], Politechnika Warszawska, [The Warsaw Uniwersity of Technology].

[7] Rusowicz, A.; Ruciński, A. 2011. The Mathematical Modelling of The Absorption Refrigeration Machines Used in Energy Systems, in Proc. of the 8th International Conference ENVIRONMENTAL ENGINEERING, Vilnius Gedimias Technical University Press-Technika, 802-806.

[8] Ruciński, A.; Rusowicz, A. 2010. The Comparative Analysis of Single and Multi-Effect Absorption Cooling Machines. Biuletyn Politechniki Lwowskiej [National University Lviv Polytechnic], 659: 8-13.

[9] Busato, F.; Lazzarin, R. M.; Noro, M. 2011. Ten years history of a real gas driven heat pump plant: Energetic, economic and maintenance issues based on a case study, Applied Thermal Engineering 31: 1648-1654. http://dx.doi.org/10.1016/j.applthermaleng.2011.02.006

[10] Grzebielec, A. 2009. Experimental study on adsorption heat pump, Archives of Thermodynamics 30: 189-200.

[11]Jędral, W. 2000. Modernization of pump installations and other conditions for introducing quantity control in combined heat and power plants and heating stations, Journal of Power Technologies 87: 45-59.

[12] Tofighi, A. 2013. Performance Evaluation of PV Module by Dynamic Thermal Model, Journal of Power Technologies 93(2): 111-121. 